Vol. 7

正 誤表

巻真行

第 2 巻 33 表 1 , 第 2 行

" 第 2 表, 表題

" 第 2 表, 経過時間

35 右上より 11

37 上より 16

38 第 1 表, アメンボの項, 各

53 左表の下, 2

", 3

64 左下より 9

68 右下より 5

" 表 題

69 左より 6

73 左下より 16

" 15

" 12

74 右上より 11

86 第 2 表予防效率

第 2 表下, 左上り 3

右下上り 4

第 6巻 68 表題上より 3 (著者名)

72 左 $5 \sim 6$

90 第 1 図

表紙裹 下より17 (著者名)
愦

0, 0-d-methyl累績死虫率

10

又び

於保信影

$\underline{0}$

- TRAID

冬期間生存し

阻止内法

$1.5 \mu$

Filamentosa

Corticiumu

$3 \sim \underline{5}$ 日

1 $\sim 5$ 日

機会的

CWV

98.7

3.5多

略冬

Yoshinari

水銀剂 $(\mathrm{N}$-acetyle

mercuri $1,2,3,6$,

tetrahydro-3, 6, -

methano-3,4,5,6,7,7,-

hexachloro

アズキ種子伝染性モザイク…

岡富善次郎
正

0, 0-dimethyl

兒糟死虫率

120

及び

於保信彦

STRAIB

冬期に形成された夏胞子は夏 期のむのより長期間生存し。 阻止円法

$15 \mu$

filamentosa

\section{Corticium vagum}

3 6日

1 6日

機械的

CMV

78.7

3.5 多

略

Yoshiya

N-ethyl

mercuri-1, 2, 3, 6,-

tetrahydro-2, 6,-

endomethano-3,4,

$5,6,7,7$, -hexachloro

カンキツ苗の没病

岡留善次郎 